\title{
New forms of oppositional politics in Erdoğan's Turkey
}

Edition 4, 2020

Dr Tezcan Gümüş \& Iain MacGillivray

DOI: 10.37839/MAR2652-550X4.23

Turkey's steady transformation from a democracy to a competitive authoritarian system has been a radical one.

Prime minister-turned-President Recep Tayyip Erdoğan today wields personalised power over the government and critical state institutions. This concentration of power has ultimately meant existing channels available to influence regime-change have shrunk dramatically. Turkish politics scholars Sinem Adar and Yektan Türkyllmaz argue that Turkey's current electoral environment is at a stage where 'constitutionally defined means of political transformation have become de facto obsolete'.

Naturally, Turkey's new authoritarianism creates a highly reduced operating environment for the Turkish opposition to contest Erdoğan's power. Recent electoral experiences indicate that despite these political transformations, there is an ongoing resistance which has not only denied Erdoğan and the Adalet ve Kalkınma Partisi (Justice and Development Party, AKP) from achieving political hegemony but is critical to maintaining political pluralism.

During the concurrent parliamentary and presidential elections in 2018 and the following local municipal elections of 2019, the Turkish opposition used the government's own 'alliance law'-designed to give the government advantage-as an opportunity to maximise their own competitiveness. It resulted in a pro-democratic 
alliance which produced an unprecedented alignment amongst Turkey's opposition parties for the municipal elections of 2019. The rapprochement between the proKurdish rights Halklarin Demokratik Partisi (Peoples' Democratic Party) with the ideologically opposing two-party alliance of the Cumhuriyet Halk Partisi (Republican People's Party) and IYI Parti (Good Party) succeeded in capturing key major cities from government control. This strategy was greatly aided by an innovative campaign that disrupted and disarmed the traditional politics of the government.

Turkey's radical electoral transformation to a highly centralised and controlled political environment spurred the opposition to reimagine and apply new methods of contestation. These methods resulted in a successful push-back against the AKP and Erdoğan's pursuit of authoritarian hegemony.

\section{Contentious politics}

Oppositional movements under authoritarian regimes are somewhat different in the way they engage in contentious politics compared to those oppositional groups who work within a democracy.

According to political scientists Charles Tilley and Sidney Tarrow, 'contentious politics' refers to the use of disruptive techniques that are aimed at changing governmental policy or to establish political change. In quasi-authoritarian systems, the opposition simply 'being there', can inject highly charged demands into electoral institutions which contest the predominance of authoritarian rule. The opposition's engagement in 'conventional' politics risks being targeted by the government who explicitly deny and reduce opportunities for the opposition to enter electoral and governmental institutions. This situation creates an adversarial relationship between the authoritarian government and opposition whereby the opposition challenges the authoritarian 'rules of the game'.

As a result, opposition repertoires and behaviour of change in reaction to their conditions. These shifts are formed by the processes of repressive politics and 
consequently resort to internalised tactics and behaviours against the state as a survival and resistance mechanism. As political scientists Dara Conduit and Shahram Akbarzadeh illustrate 'oppositional characteristics and behaviour are not isolated from ruling governments and are inevitably shaped by [the] interaction with an authoritarian regime' highlighting the 'often-symbiotic nature of governmentopposition relations'.

Authoritarian forms of government can often push the opposition to develop new forms of contestation because 'repression is more likely to provoke even higher levels of challenge, both nonviolent and violent, rather than deter contention.' Shifts in opposition methods and behaviour arise to maximise opportunities and maintain autonomy in the face of the ever-reducing political space. Contentious politics reveals new methods of challenging government hegemony and are shaped by how the opposition chooses to respond to their operating environment. Furthermore, it can help explain how challengers in quasi-authoritarian settings survive, consolidate and advance their agendas.

\section{Electoral alliances: new form of contentious politics}

In the previous presidential elections of 2014 and parliamentary elections of 2015, there were notable examples of cooperation amongst opposition parties. This cooperation resulted in a pro-democracy bloc that pushed back against Erdoğan's increasing authoritarian rule. The formal transition to a competitive authoritarian system after the constitutional change to a presidential system in 2017, however, has sharpened the opposition's efforts at cooperation. This transition has given the opposition leverage, demonstrating the stark power differences in governmentopposition relations.

When Erdoğan called snap parliamentary and presidential elections in 2018-which was seemingly designed to block the recently established IYI from competing-the 
main opposition CHP came to IYI's aid, utilising an existing legal loophole in Turkey's parliamentary laws to temporarily transfer 15 of its parliamentarians across to IYI, enabling the newly created party to meet the minimum number of deputies to establish a parliamentary group and contest the upcoming elections.

A new 'electoral alliance' law passed by the AKP government on 3 March 2018 permitting electoral alliances between parties that sparked the most important development in opposition alignment. The legislative change was made in light of the 2017 constitutional referendum outcome that showed Erdoğan's 51.4 percent win did not assure him a clear victory in the next elections, despite the uneven playing field in his favour. Therefore, a victory in presidential elections and maintaining AKP's legislative authority could not be achieved without Milliyetçi Hareket Partisi (Nationalist Action Party, MHP) numbers, ultimately pushing Erdoğan to legislate favourable parameters for the elections in 2018. Under this legislative setting, the AKP quickly formalised its pre-existing partnership with MHP under the Cumhur Ittifakı (People's Alliance) banner.

The law, however, presented a space for Turkey's ideologically dispersed opposition parties to work together against Erdoğan's increasingly authoritarian political system. In response to the AKP-MHP alliance, the opposition formed the Millet Ittifakı (Nation Alliance) made up by the secular centre-left CHP, centre-right nationalist IYI, the Islamist Saadet Partisi (Felicity Party, SP), and centre-right Demokrat Partisi (Democrat Party, DP). The political opening enabled opposition parties to come together over a common set of principles to roll back the authoritarian system and strengthen their position, as outlined by CHP leader Kemal Kılıçdaroğlu during an interview:

We, as different political parties, are coming together as a show of democratic strength and unity. This is a first in Turkey. As diverse political parties we have come together to strengthen democracy, to strengthen human rights, to solve outstanding problems through a democratic parliamentary system. This is very important to us. 
The opposition solidified this new alliance by signing a pro-democratic declaration pledging to 'end polarization, instill independence of the judiciary and the rule of law, and ensure basic rights and freedoms'. Moreover, one of the primary aims was to re-instate a strengthened parliamentary system.

The legislative change also offered smaller oppositional parties a path to enter parliament by getting around Turkey's 10 percent electoral threshold, often referred to as 'the world's most unfair election system'. Ironically, this law increased the chances of greater plurality in parliament which was a highly unlikely proposition before the law change, especially after 17 years of AKP dominance in the Assembly.

The AKP and Erdoğan's increasing authoritarianism and hold over the state encouraged the search by the opposition for new political possibilities to engage in contentious politics and maximise their claims against the regime. This search for new political possibilities was indeed a unique development. When we look back at opposition activity over the years it has been their pronounced fragmentation and inability to bridge their differences that is a key reason for enabling Erdoğan to strengthen his rule, whilst tightening the operating space for them to be an effective opposition. In doing so, the alliance maximised the opportunity to challenge the structure which maintains Erdoğan's predominance in electoral politics.

While the People's Alliance presented Erdoğan as its joint-presidential candidate in early May 2018, the opposition camp failed to unite behind a single nominee. The CHP nominated Muharrem Ince, an internally popular, charismatic politician with a national profile, whilst IYI and SP nominated their respective leaders, Meral Akşener and Temel Karamollaoğlu. All three opposition leaders campaigned independently, but they ultimately worked off the same platform as the Nation Alliance's democratic pledge. A critical component of their cooperation against Erdoğan included refraining from criticising each other while all three candidates pledged to endorse each other in a potential runoff and serve as vice-presidents in a future cabinet. For instance, Ince in an interview on FOX Türk stated: 
In the event I am not in the second round of voting, that does not matter. I will again get back on top of the car and support the other candidate against Erdogan. It doesn't matter if it is Honourable Karamollaoğlu or Honourable Akşener. We must work together to change the polarisation and the zero-sum nature of politics in Turkey. It only drags the country into a swamp.

Throughout the campaign the opposition ran a highly effective and innovative strategy against the unequal conditions and constricted political space in which it had to operate. Ince, Akşener, Karamollaoğlu and Kılıçdaroğlu, as key symbols of the alliance, appeared regularly on the few independent media outlets: Fox Türk, Halk Tv, Deutsche Well Türkçe and Haber Türk and ran a tireless campaign schedule across the country. For instance, Ince organized 107 rallies in 75 cities and Akşener visited 81 cities from the time she established IYI in late 2018. Most of the rallies and speeches were broadcast live on social media platforms, allowing the alliance to reach audiences and work around the monopoly of the media landscape the People's Alliance enjoyed. The successful campaigning by the opposition occurred in spite of the imbalances skewed towards the AKP and Erdoğan. The People's Alliance financed their campaign with presidential and state funds as well as making sure the opposition received near to zero television time on Turkish TV channels owing to the AKP's monopoly of the media landscape.

\section{A step toward Turkish-Kurdish alignment}

The pro-Kurdish rights Halklarin Demokratik Partisi (Peoples' Democratic Party HDP), owing to the traditional Turkish-Kurdish cleavages of the party system was not part of the opposition alliance and contested the parliamentary elections independently. They listed their former co-leader and incarcerated Selahattin Demirtaş as its presidential nominee. The Nation Alliance's need to increase their electoral reach and present a legitimate democratic platform incentivised the parties and candidates to move beyond their traditional political identities and appeal to the Kurdish electorate. This strategy also offset the AKP's attacks on the Kurdish 
movement, and the very nationalist polemic it had employed throughout the campaign.

Ince's presidential campaign embodied this outreach strategy the most. He broke with the CHP's dominant nationalistic character and visited Demirtaş in prison. He also held lively campaigns in Kurdish-majority cities, often attracting large crowds where his speeches were characterised by democratic inclusivity. Moreover, Ince promised to implement a long-time demand of the pro-Kurdish movement to devolve administrative powers to elected local officials in line with the European Charter of Local Self-Government. Outreach by the opposition helped loosen traditionally entrenched suspicions against the CHP (which was long considered a haven for antiKurdish sentiment by citizens in the south east of Turkey). The benefits of this new strategy can be seen through statements to $B B C$ Türkçe from individuals who went to Ince's Diyarbakır rally:

We will meet those hands that reach out to us to attain the promise of peace. CHP is the only party that keeps the hopes of peace alive among the existing parties. My vote is for HDP and Demirtas, but if HDP and CHP agree in the second round, we will give our vote to Muharrem İnce.

Similarly, Akşener from the IYI Parti attempted to reach out to Kurds through her democratic platform and meetings in Kurdish majority areas. Her nationalist credentials and former role as Interior Minister in the 1990's (a rather dark period in Turkish-Kurdish relations) was her weakness for the Kurdish vote-base. Akşener's centre-right nationalist position limited her appeal and success with Kurdish voters, but her campaign strategy demonstrated political actors can pragmatically overlook ideological constraints in order to organise greater mobilisation to challenge the regime in episodes of contentious politics.

At the end of the 2018 election, the final ballot indicated the Nation Alliance was met with limited success and Erdoğan retained his hegemonic authority. He won the presidential election in the first-round (53 percent) and AKP came out on top in 
terms of a parliamentary majority (43 percent). It should be remembered though that the 2018 election was held under a state of emergency implemented after the July $16^{\text {th }}$ Coup attempt in 2016 where Council of Europe observers declared, 'greatly limited the space for democratic debate and the expression of pluralism, let alone political dissent'. The outcome was hardly a decisive victory for the government. The AKP actually lost its majority, and only maintained its parliamentary control due to its alliance with the MHP (11 percent) and the SP and the DP won three seats in total through their alliance with CHP and IYI. It showed despite the fast-shrinking political space and limited openings for the opposition, they were able to adapt to its authoritarian environment and remain in the contest.

\section{Municipal elections: A dramatic shift in contestation}

The Nation Alliance's overtures to the Kurds and democratic platform allowed it to cultivate an even more dramatic oppositional strategic political alignment for the municipal elections in the following year. The 2019 local elections witnessed all the major parties retain their alliances. The AKP-MHP block pursued a strategy of nominating joint candidates and supporting each other in 51 cities; similarly, the CHP and IYI agreed to work together in 47 cities. In particular, the CHP-IYI alliance aimed to win control of Turkey's largest municipalities from the AKP or the MHP, which included having joint-candidates in Istanbul, Ankara, Bursa, Antalya, and Adana.

The election witnessed an unprecedented political compromise to the seemingly intractable Turkish-Kurdish cleavage. The formation of an unspoken rapprochement between CHP-IYI and the HDP based around joint principles and demands against the regime was key to what would be the opposition's victory in these municipal elections. The HDP chose not to nominate candidates in key metropolitan municipalities of Istanbul, Izmir and Adana. Demirtaş' statement from prison to the 
HDP base to cast a vote against 'fascism' to 'create an opportunity for democracy and peace to arrive' was taken as implicit support for the CHP-IYI candidates to maximise opportunity for opposition victory in the major cities.

The results of the municipal elections provided the opposition's best electoral performance against the AKP and Erdoğan's authoritarian regime. Though nationally the AKP-MHP alliance garnered a majority of votes at 52 percent, it lost to the CHPIYI joint candidates in Turkey's key cities Ankara, Izmir, Adana and Antalya. In addition, the HDP maintained its dominance over most Kurdish populated provinces in the country's south east.

The most critical outcome was the opposition candidate Ekrem Imamoğlu's victory of the Istanbul mayorship. With 14,000 more votes in the March 31st election, Imamoğlu snatched Istanbul from 25 years of control by Islamist parties. The city was a symbolic stronghold for these parties, but was the AKP's main source for patronage politics owing to the city's economic size and weight in Turkey.

Turkey's electoral committee packed with Erdoğan supporters controversially voided the result and announced a re-run for the $23^{\text {rd }}$ of June. In the lead-up to Istanbul's second election, the HDP worked even harder to mobilise their estimated one million voters for Imamoğlu by running a door-to-door canvassing campaign and offering free transportation back to Istanbul for residents holidaying outside the city. The party also gathered some 15,000 supporters and affiliated lawyers to monitor the voting process and ballot boxes to prevent cheating against Imamoğlu. Similarly, five-days before the second ballot, Demirtaş was more direct in urging HDP supporters to cast their votes for the opposition candidate. The outcome witnessed the Kurds, who once voted for the AKP, abandon the party along with 80 percent of HDP voters casting a ballot for the CHP-IYI candidate. Ultimately, Imamoğlu increased his winning margin to 800,000 votes and reclaim his victory. 


\section{Disrupting authoritarian power with new politics}

The support from HDP was made easier because of a new generation of politics expressed by CHP-IYI candidates in the major cities, particularly by the Istanbul mayoral candidate. Imamoğlu did not waiver from a calm demeanour and message of inclusiveness, based upon the CHP's new and innovative campaign strategy of the Radikal Sevgi Kitabı (The Book of Radical Love). The consequences of repeated electoral losses to Erdoğan and the AKP forced a rethinking of the traditional campaign politics of amplified polarisation and aggression. For instance, faced by a polarising counter-campaign from Erdoğan, the AKP and its junior ally, MHP portrayed the opposition as an existential security threat to Turkey. Despite these accusations and the clear injustices of the first election result overturned by Erdoğan's government, Imamoğlu held resolutely to the Radical Love approach during his campaign to the re-run election.

The Radical Love strategy neutralised the AKP's political polarising rhetoric, extended Imamoğlu's appeal to voters who made up the AKP's support base, and left Erdoğan's AKP with few promising options for a successful counterattack. More importantly, it helped Imamoğlu successfully defuse and disarm the governing party's aggressive populist arsenal. Imamoğlu's responsiveness to voters' demands through focusing on the day-to-day concerns of Istanbul residents rather than high politics was an extremely effective strategy. Ultimately, the Radical Love approach was a key reason for the victory in Istanbul, as it attracted a broad coalition of voters including those who traditionally voted for Erdoğan, and supporters of the HDP.

The politics of Radical Love effectively disrupted and disarmed the government's polarising methods, which had been central to its electoral successes against opponents. Moreover, it allowed opposition candidates to extend their appeal to constituents who otherwise would have voted for the government in Turkey's increasingly polarised atmosphere. Ultimately, faced by the growing hegemony of 


\section{MELBOURNE ASIAREVIEW}

the government, Turkey's opposition were forced to shift their methods of contestation from isolation to unification. Unification by the opposition saw not only inter-opposition shifts to deny Erdoğan the opportunity to consolidate his authoritarian hegemony by extending the spaces for political pluralism, but also democratic transformations within themselves. Nonetheless, this is a contest that is far from over and will continue to shape electoral politics and ultimately the future of Turkey.

With incoming US president Joe Biden, Erdoğan will see a sharp rise in criticism from Washington compared to the Trump administration. In previous interviews, Biden labelled Erdoğan a 'tyrant', expressing his wish to support the Turkish opposition to remove Erdogan through the ballot box. But, Turkey's opposition is extremely unlikely to work with the Biden administration against Erdoğan. Yet, they will quietly welcome any sharp criticism and pressure from the Biden White House in the hope it will force Erdoğan to take democratising steps, bringing greater opportunities of contention and contestation.

Authors: Dr Tezcan Gümüş \& Iain MacGillivray

Image: An opposition march near Sakarya in 2017. Credit: Mark Lowen/Wikimedia

Maintaining pluralism in authoritarian systems: Lessons from Turkey and beyond 